from South Africa that Herschel had made no such discoveries as the Sun described, good New Yorkers were only reinforced in their religious beliefs. Surely the visions that he had described were a sign of the religious insights that would await us, once science moved forward enough?

The Sun and the Moon is a wonderful cautionary tale, especially in an era like our own, when, for example, no candidate is likely to be elected president of the United States if he professes disbelief in either science or religion. The mix seems illogical, but only if one misses how the two domains are popularly understood. Most people do not understand the details of how science works. They just see the impressive results of what it can achieve - whether it is steam engines in Locke's era or iPhones in ours. The more technology advances, the more such blind trust is encouraged. Locke and Dawkins might well weep, but a popular life that shares none of their ultimate views goes on.

Unfortunately, Goodman tells the story poorly, undecided if his book is an account of Locke's hoax or a general social history of the mass press and ways that cynics and reformers dealt with popular credulity. But his research is excellent, and if publishers fund him to write a wider account, it would be well worth reading.

David Bodanis is a writer based in London and the author of Passionate Minds.

\title{
Tale of a clockwork computer
}

\section{Decoding the Heavens: Solving the Mystery of the World's First Computer \\ by Jo Marchant \\ William Heinemann/Da Capo Press: 2008/2009. 330 pp/288 pp. £12.99/\$25}

It is appropriate that Arthur C. Clarke recommended this book before his death in March 2008. Decoding the Heavens tells the story of the 2,000-year-old Antikythera Mechanism and its decipherment. The tale encompasses diving, shipwrecked treasure, scientific puzzles, cutting-edge technology and computing, all of which Clarke knew from the inside. Moreover, he had a walk-on role.

The Antikythera Mechanism is an ancient Greek artefact comprising more than 30 precisely cut bronze gear wheels, dials and pointers held in a wooden case.

Clarke began to publicize the mechanism in 1959, perhaps encouraged by his friend Jacques Cousteau, who in 1953 had reinvestigated an ancient shipwreck off the Greek island of Antikythera, which had been salvaged by roving Aegean sponge divers in 1900-01. In 1965, Clarke tracked down the mechanism's encrusted remains languishing in a cigar box at the National Archaeological Museum in Athens, later televising it in Arthur C. Clarke's Mysterious World in 1980. If the ancient Greeks had been able to build on the knowledge required to make the mechanism, he told a Smithsonian
Institution audience in 1973, by now humans might be exploring the nearer stars, not merely the inner Solar System.

Yet, as Clarke admits on the book's jacket, the Antikythera Mechanism remains "underrated". The instrument was known only to a small circle of enthusiasts until a paper was published in 2006 explaining its operation, based on X-ray images of the interior and a new technique for illuminating previously hidden surface inscriptions (T. Freeth et al. Nature 444, 587-559; 2006). Jo Marchant, then a Nature staff journalist, wrote a news feature to accompany the paper, and the book grew from her research. Decoding the Heavens is Marchant's first book and is aimed squarely at the non-scientific reader, but is serious about the science. Her gripping and varied account will propel the mechanism to greater fame, although it may never achieve the celebrity of the Rosetta Stone that it probably deserves.

The complexity of the mechanism suggests that the ancient Greeks had achieved a level of clockwork technology not reached again until the Industrial Revolution of the eighteenth century. "It's hard to overestimate the uniqueness of the find. Before the Antikythera Mechanism, not one gearwheel had ever been found from antiquity, nor indeed any example of an accurate pointer or scale. Apart from the Antikythera Mechanism, they still haven't," Marchant explains.

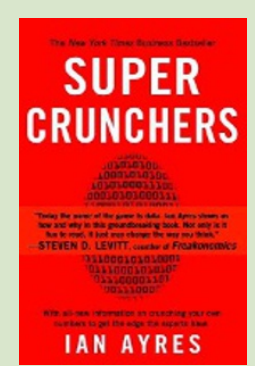

\section{Super Crunchers}

\section{by lan Ayres}

(Bantam Books, \$14.00)

Ayres explains how data mining, statistics and number crunching are used increasingly by everyone and everything from Internet search engines to your family physician. Showing how this affects people directly, he gives advice on how to defend ourselves against the negative sides of this data blitz.

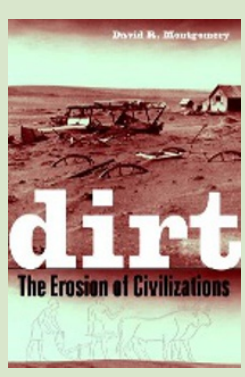

Dirt: The Erosion of Civilizations

by David Montgomery

(Univ. California Press, \$16.95)

Montgomery explains how the collapse of ancient civilizations is linked to soil erosion and shows that this can be seen today. "Societies prosper and persist best when they figure out ways to keep their soil where it belongs and not treat it as if it were dirt cheap," wrote Eric A. Davidson (Nature 447, 777-778; 2007). 
The original 1900-01 dive was the first archaeological exploration of a wreck, undertaken decades before Cousteau's invention of the scuba apparatus. After describing its drama, Marchant turns to the scholars from many countries who tried to date and interpret the mechanism over the next century. In the 1960s and 1970s, the leading investigator was the late science historian Derek de Solla Price of Yale University, who published Gears from the Greeks (American Philosophical Society, 1974). Since the 1990s, two rival explanations have emerged: one from Michael Wright, a former curator at the Science Museum in London, who is inspired by de Solla Price, and the other from the multidisciplinary team that published in Nature, led by mathematician and film-maker Tony Freeth and Mike Edmunds, an astronomer at Cardiff University. Marchant's handling of the rivalry is excitingly tense.

Damaged Greek inscriptions initially dated the mechanism to between the second century $\mathrm{BC}$ and the second century AD. Radiocarbon analysis dated the ship's wooden hull to between 260 and 180 BC, although the ship could have sailed later. The design of the wreck's pottery amphorae narrowed the date to the first half of the first century вС. Silver and bronze coins found by a second Cousteau expedition in 1976 showed the ship sank between 70 and 60 вС, probably while sailing from Pergamon, on the coast of Asia Minor, towards Rome.

The mechanism was initially thought to be an astrolabe. But its gear wheels suggested another use, as astrolabes do not need gears. De Solla Price imagined it was a calendar computer, but this did not explain the ratios of teeth on the gears. Wright now favours a planetarium explanation, whereas Freeth's team believes it is an instrument for predicting eclipses. Freeth prefers to call it a 'calculator' rather than a 'computer', whereas Marchant, following historian Doron Swade's definition that a computer can display its calculated numbers on a scale, uses the latter. In both explanations, the mechanism's builders assumed that Earth is at the centre of the heavens, as believed by Greek astronomers and philosophers except for the heliocentric Aristarchus of Samos, and that the movement of the heavenly bodies is based on epicycles.

Marchant's fascinating final chapter asks who made it, and why. The inventions of Archimedes in the third century вС might have influenced it; an epigraphic analysis published earlier this year hints at a link with his home city of Syracuse (T. Freeth et al. Nature 454, 614-617; 2008). The astronomer Hipparchus may also have inspired its design, but was probably dead before its construction. The philosopher Posidonius, who lived at the right time, is a strong candidate; his student Cicero mentions that Posidonius built an instrument that reproduced the "motions of the Sun, the Moon and the five planets".
The mechanism's purpose may have been for astrology, in which Hipparchus apparently believed, but more likely it had no practical use. Like the orreries of the Enlightenment, it was probably one among many luxury gadgets for the educated Greek and Roman elite the only example of its kind to survive. "The Antikythera Mechanism," Marchant concludes, "was originally meant as a celebration of the heavens."

Andrew Robinson is a visiting fellow at Wolfson College, Cambridge. He is the author of Lost Languages: The Enigma of the World's Undeciphered Scripts and The Story of Measurement. e-mail:ar471@cam.ac.uk

\section{Liver satire delivers}

\section{Liver: A Fictional Organ with a Surface Anatomy of Four Lobes by Will Self}

Viking: 2008.288 pp. $£ 18.99$

We live, by and large, Panglossian lives, naively reading purpose into the world, and into ourselves. Confronted by our bodies, we wonder at their watch-like precision. Each part of us does something. A heart pumps blood. A skull shields the brain. Eyes see. Hands grip.

When we look at the liver, however, we see not a tool for living, but a living thing - and this is an uncomfortable proposition. The liver has a plethora of functions: storage of the carbohydrate glycogen, decomposition of red blood cells, production of blood plasma proteins, detoxification, bile production - and that's without even mentioning its regulatory abilities. It intimidates us by its efficient ubiquity.

Will Self's new book, Liver, is not body horror in the science-fiction sense. For Self, as aficionados of the author will expect, Liver is satire. In his vision, our livers are more valuable than we are, more able, more alive. The liver is the only internal organ in the body that can regenerate itself to a significant extent. Yet still we contrive, over the course of our lives, to squander its magnificent estate.

The four 'lobes' of Self's book are individual stories - his strongest in years. With a little intertwining of narrative, his peculiar tales of abuse, disease and decay largely follow their own paths. Cirrhosis, cancer, hepatitis and, with a nod to Greek mythology, a vulture wander among the human protagonists as equals. Self's satire is classical rather than radical, rooted more in Alexander Pope than Jonathan Swift. Diseased flesh takes plenty of collateral damage, but contemporary behaviour is Self's real target. "Confronted with the nobility of feeling, high culture and deep spirituality", Self - like the malevolent bar fly of his first story, 'Foie Humain' - "sees nothing but the stereotypic behaviours of anthropoid geese."

Satire depends for its success on a pitiless accuracy. Self's prose veers between the appetizing and the nauseating, yet it is almost always on the nail: proof that the more accurately you describe a thing, the more surreal it seems. His vivid characters include a cancer sufferer being hustled towards her elective suicide by her daughter's poor timekeeping, the determined alcoholic gorging of a hapless barman, and a dangerously unmotivated Harley Street hepatologist. These sketches
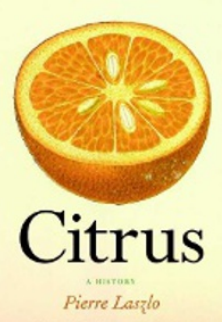

Pierre La

\section{Citrus: A History}

by Pierre Laszlo (Univ. Chicago Press, \$17.00)

Laszlo describes the chemistry of citrus fruits.

"His succinct explanations of the Maillard and caramelization reactions when describing how to make marmalade, and his notes on foams, phase separation, and the volatility of aromas when explaining how to make a sabayon, justify the cost of the book on their own," wrote Peter Barham (Nature 450, 479; 2007).

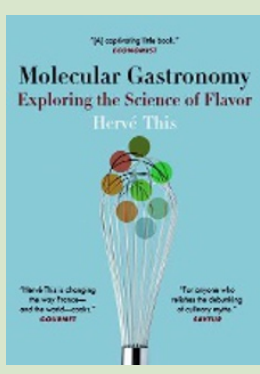

\section{Molecular Gastronomy: Exploring the Science of Flavor}

by Hervé This (Translated by Malcolm DeBevoise) (Columbia Univ. Press, \$19.95)

French experimental chef, This, opens up the kitchen to scientific experiments. In this enjoyable book, he debunks old rules and superstitions about cooking, and shows how food can be looked at, prepared, cooked and tasted in new ways. 